\title{
Performance of exhaust-protective (class I) biological 'safety' cabinets
}

\author{
S. W. B. NEWSOM
}

From Sims Woodhead Memorial Laboratories, Papworth Hospital, Papworth Everard, Cambridgeshire, UK

SUMMARY Nineteen open-fronted (class I) safety cabinets were subjected to spore containment and airflow tests, which suggested that a flow of $0.75 \mathrm{~m} / \mathrm{s}$ was the minimum required for safe operation; further tests on three of the cabinets were repeated at different air speeds and confirmed this. The airflow is required to overcome the effect of laboratory or external air currents. Contamination of surfaces (including the operator's hands) by aerosols liberated inside the cabinets was investigated and found to depend more on turbulence within the cabinet (as from a restricted front opening) than on the number of air changes. The findings suggest that the product protection provided by a well-designed class I cabinet might equal that of a class II (laminar flow) unit.

For many years aerosols have been suspected of causing laboratory-acquired infection, and the American Public Health Association Surveys (Pike, 1976) confirmed that up to $85 \%$ of such infections are 'silent' and presumptively airborne. Thus the use of a 'safety cabinet' is indicated for work with dangerous pathogens, and by 1909 one existed fitted with a cotton wool inlet filter, rubber gloves, and a 'disinfected' exhaust. Later units, which used a gas burner to provide a draught and incinerate the exhaust, had some success (van den Ende, 1943; Shepard et al., 1945). Filters were then introduced together with fans able to provide an airflow of approximately $0.25 \mathrm{~m} / \mathrm{s}$ across the working aperture (Solotorovsky et al., 1953). Wedum's (1953) statement that $0.25 \mathrm{~m} / \mathrm{s}$ air velocity provided adequate containment was refuted by Barbeito and Taylor (1968), and $0.5 \mathrm{~m} / \mathrm{s}$ was specified by Williams and Lidwell (1957) for the Public Health Laboratory Service cabinet. The Porton glove box (Darlow, 1961) had a fan able to provide an air velocity of $0.5 \mathrm{~m} / \mathrm{s}$ through the glove ports in case of seal failure, or through the alternative 'hand holes'.

Despite such specifications the presence of inadequate but commercially available cabinets (Line, 1972) caused the Department of Health and Social Security to commission a survey on the 'operator protection' provided by exhaust-protective (class I) cabinets of different makes. Although the main aim was to test containment of aerosols within the cabinets as sold, some design faults became apparent, and this paper records tests to explore the

Received for publication 22 November 1978 containment efficiency and the effects of differing airflows on both the operator and product protection of a number of class I cabinets. The results relate to the cabinets as tested and do not necessarily apply to others of the same model because installations vary.

\section{Material and methods}

Tests were done on a range of cabinets; some loaned by manufacturers were installed at Papworth, others were in use at laboratories in East Anglia or London. Three Papworth-based units had provision for altering the airflow. Three parameters were studied: containment of microbial aerosols, contamination of interior surfaces, and airflows.

\section{MICROBIAL STUDIES}

Microbial studies were based on challenge aerosols of Bacillus subtilis spores $\left(2 \times 10^{4}\right)$ liberated in a 10-second burst from a Bird Micronebuliser (British Oxygen Co) operated at $10 \mathrm{psi}(69 \mathrm{kPa})$. Airflows were measured with an electronic vane anemometer $O$ (Airflow Developments RM 27) or a thermoanemo- N meter (Prossor Scientific Instruments), both of which could be attached to a chart recorder. The testsystem has already been described in detail (Newsom, 1974).

Containment of microbial aerosols (operator protection)

This was measured by liberation of a challenge aerosol within the cabinet and sampling 551 of laboratory air in 2 minutes with a slit sampler 576 
(Cassella) placed before the working aperture. Tests were made on containment in commercially available cabinets as seen, on the effects of varying airspeeds on spore leakage, and on the effect on containment of turbulence in laboratory air. Nineteen commercially available (or prototype) cabinets were tested. Challenge aerosols were liberated in sets of 10 or 12 from a micronebuliser sited $15 \mathrm{~cm}$ behind the working aperture, $5 \mathrm{~cm}$ above the floor, at one side of the cabinet pointing across it. Extra tests were done with $2 \times 10^{6}$ spores, with the micronebuliser pointing forwards and while an operator was opening and closing 12 screwcapped bottles in the cabinet. A more severe challenge was presented by placing the micronebuliser $2.5 \mathrm{~cm}$ behind the working aperture pointing directly into the laboratory, a test made even more stringent by being repeated with the operator walking to and fro past the cabinet. The effect of varying the air speed at the front opening was investigated in three cabinets, using these latter tests and different spore concentrations. Finally, a set of tests on a normally 'good' cabinet was run in the presence of turbulence generated by slamming the laboratory door (with the window shut).

Control counts were made of room air after setting up the apparatus, and of challenge aerosols with the cabinet switched off. Some earlier tests were rendered invalid by persistence of these control aerosols, so thereafter they were done at the end of the day, and an 'air scrubber' capable of filtering $9 \mathrm{~m}^{3}$ air $/ \mathrm{min}$ was used for 30 minutes between tests in an attempt to reduce background contamination.
Contamination of interior surfaces (product protection)

This was tested by exposing two $25 \mathrm{~cm}^{2}$ agar-filled assay dishes side by side on the cabinet floor beneath the track of a challenge aerosol for 2 minutes-and in a few cabinets by spraying a challenge from the laboratory (15 cm from the working aperture) at the cabinet and exposing $9 \mathrm{~cm}$ diameter agar plates along the front edge. Further tests were done to compare the effects of an open or restricted working aperture (glove ports) on surface contamination, using an open-fronted cabinet with a variable speed fan and a plastic cover containing two ports, so that similar airflows could be set through each type of aperture. As well as using assay plates, the author's right hand clad in a sterile plastic glove was used as a test surface. The hand was waved in a standard way inside the cabinet while aerosols were liberated $35 \mathrm{~cm}$ away. The fingers were then imprinted on an agar plate. All the culture plates were incubated at $36^{\circ} \mathrm{C}$ for 18 hours and then left for 24 hours at room temperature. Colonies with the typical gold pigment and characteristics of $B$. subtilis were then counted.

\section{AIRFLOW MEASUREMENTS}

Airflows were recorded at five points across the working aperture of all the cabinets. Variations in flow were measured in various units with the electronic anemometer linked to a recorder. Air velocities were also recorded across the working aperture of a $120 \mathrm{~cm}$ wide cabinet set in a small room. Finally, recordings were made of reverse air-

Table 1 Properties of 19 class I cabinets

\begin{tabular}{|c|c|c|c|c|c|c|}
\hline Maker & No. & $\begin{array}{l}\text { Air speed } \\
(\mathrm{m} / \mathrm{s})\end{array}$ & $\begin{array}{l}\text { Air changes } \\
\text { per minute }\end{array}$ & Containment & $\begin{array}{l}\text { Surface } \\
\text { contamination }\end{array}$ & Comment \\
\hline $\begin{array}{l}\text { Phase separations } \\
\text { Luckhams } \\
\text { Luckhams } \\
\text { Luckhams } \\
\text { Bassaire PC II } \\
\text { Microflow } 10036 \\
\text { EDL } \\
\text { Slee } \\
\text { Microflow } 1140104 \\
\text { EMI } \\
\text { LEEC } \\
\text { Hepaire } \\
\text { Foramaflow } \\
\text { LTE } \\
\text { Pathfinder } \\
\text { Bassaire PC MSC } \\
\text { Searle } \\
\text { Microflow prototype }\end{array}$ & $\begin{array}{r}1 \\
2 \\
3 \\
4 \\
5 \\
6 \\
7 \\
8 \\
9 \\
10 \\
11 \\
12 \\
13 \\
14 \\
15 \\
16 \\
17 \\
18 \\
19\end{array}$ & $\begin{array}{l}0.035 \\
0.04 \\
0.06 \\
0.4 \\
0.5 \\
0.6 \\
0.6 \\
0.6 \\
0.7 \\
0.85 \\
0.88 \\
0.97 \\
1 \\
1.05 \\
1.05 \\
1.05 \\
1.1 \\
1.5 \\
1.5\end{array}$ & $\begin{array}{c}1 \\
1 \\
2 \\
15 \cdot 7 \\
20 \cdot 9 \\
20 \cdot 9 \\
6 \cdot 8 \\
21 \\
38 \\
20 \\
50 \\
30 \\
24 \\
30 \\
41 \\
37 \\
9 \cdot 2 \\
22 \cdot 5\end{array}$ & $\begin{array}{l}\text { Nil } \\
\text { Nil } \\
\text { Nil } \\
\text { Poor } \\
\text { Poor } \\
\text { Poor } \\
\text { Poor } \\
\text { Good } \\
\text { Poor } \\
\text { Good } \\
\text { Good } \\
\text { Good } \\
\text { Excellent } \\
\text { Excellent } \\
\text { Excellent } \\
\text { Excellent } \\
\text { Good } \\
\text { Good } \\
\text { Excellent }\end{array}$ & $\begin{array}{l}\text { Heavy } \\
\text { Heavy } \\
\text { Heavy } \\
\text { Heavy } \\
12 \\
50 \\
\text { Heavy } \\
85 \\
4 \\
2 \\
6 \\
1 \\
1 \\
1 \\
12 \\
35 \\
66 \\
3\end{array}$ & 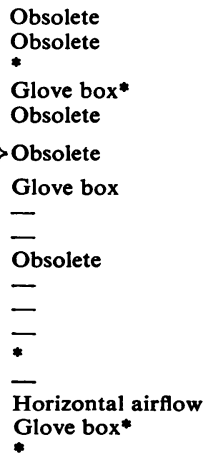 \\
\hline
\end{tabular}

Figures under 'Surface contamination' = average number of viable particles deposited on a $25 \mathrm{~cm}$ square dish.

* Prototypes-not sold commercially.

EDL = Engineering Developments Ltd.

EMI = Electrical and Mechanical Industries.

LEEC = Laboratory and Electrical Engineering Company.

LTE = Laboratory and Thermal Electric. 
Table 2 Summary of the effect of different airflows in three cabinets

\begin{tabular}{|c|c|c|c|c|c|c|c|c|c|c|c|}
\hline \multirow{2}{*}{$\begin{array}{l}\text { Cabinet } \\
\text { No. }\end{array}$} & \multirow[t]{2}{*}{ Conditions } & \multirow{2}{*}{$\begin{array}{l}\text { Challenge } \\
\text { No. of } \\
\text { spores }\end{array}$} & \multirow{2}{*}{$\begin{array}{l}\text { Control } \\
\text { room } \\
\text { air }\end{array}$} & \multicolumn{8}{|c|}{ Air speeds across working aperture $1 \mathrm{~m} / \mathrm{s}$} \\
\hline & & & & 1 & 0.75 & 0.6 & 0.5 & 0.4 & $0 \cdot 3$ & $0 \cdot 2$ & 0 \\
\hline 1 & $\begin{array}{l}\text { Quiet } \\
\text { Quiet } \\
\text { Quiet } \\
\text { Walking } \\
\text { Walking } \\
\text { Walking }\end{array}$ & $\begin{array}{l}2 \times 10^{6} \\
2 \times 10^{6} \\
2 \times 10^{5} \\
2 \times 10^{5} \\
2 \times 10^{5} \\
2 \times 10^{5}\end{array}$ & $\begin{array}{l}2 \\
4 \\
5 \\
0 \\
2\end{array}$ & $\begin{array}{l}1 \\
5 \\
6 \\
3\end{array}$ & $\begin{array}{l}6 \cdot 6 \\
6 \\
5 \\
1 \\
5\end{array}$ & $\begin{array}{c}11 \cdot 4 \\
7 \\
8 \\
3 \\
7\end{array}$ & $\begin{array}{c}5 \cdot 4 \\
5 \\
32 \\
15\end{array}$ & $\begin{array}{l}17 \cdot 4 \\
15 \\
6 \\
+t+t \\
74\end{array}$ & $\begin{array}{r}25 \\
10 \\
120 \\
++t+\end{array}$ & $\begin{array}{r}>320 \\
315 \\
168 \\
++++\end{array}$ & $\begin{array}{l}+++t \\
++t \\
607 \\
+++t\end{array}$ \\
\hline 2 & $\begin{array}{l}\text { Quiet } \\
\text { Quiet } \\
\text { Walking } \\
\text { Walking } \\
\text { Walking }\end{array}$ & $\begin{array}{l}2 \times 10^{4} \\
2 \times 10^{4} \\
2 \times 10^{4} \\
2 \times 10^{4} \\
2 \times 10^{4}\end{array}$ & $\begin{array}{l}1 \\
2 \\
2 \\
2 \\
1\end{array}$ & $\begin{array}{l}1 \\
1\end{array}$ & $\begin{array}{l}0 \\
0 \\
0 \\
2 \\
2\end{array}$ & $\begin{array}{r}0 \\
1 \\
11 \\
9 \\
0\end{array}$ & $\begin{array}{c}10 \\
0 \\
61 \\
++ \\
32\end{array}$ & $\begin{array}{c}61 \\
0 \\
28 \\
++ \\
++\end{array}$ & $\begin{array}{r}47 \\
46 \\
++\end{array}$ & $\begin{array}{l}36 \\
61\end{array}$ & $\begin{array}{l}22 \\
+++t \\
104 \\
++++ \\
280\end{array}$ \\
\hline 3 & $\begin{array}{l}\text { Quiet } \\
\text { Quiet }\end{array}$ & $\begin{array}{l}2 \times 10^{8} \\
2 \times 10^{3}\end{array}$ & $\begin{array}{l}0 \\
2\end{array}$ & $\begin{array}{l}1 \\
3\end{array}$ & $\begin{array}{l}2 \\
3\end{array}$ & $\underline{2}$ & $\begin{array}{l}15 \\
45\end{array}$ & 15 & $\begin{array}{r}64 \\
>100\end{array}$ & 58 & $\begin{array}{l}+++t \\
100\end{array}$ \\
\hline
\end{tabular}

Figures = average counts (5-10 tests each) of viable spore particles recovered/55 litres of laboratory air at the stated speeds. ++ Semiconfluent growth; ++++ Confluent growth.

flow on a stormy day in a cabinet with an exhaust port facing directly into the wind.

\section{Results}

\section{CABINET TESTS}

Table 1 gives the results of tests on 19 cabinets; two (5 and 6) were the same model. Containment is based on an average 70 challenges/cabinet. Background counts of up to 5 viable particles/55 1 of room air appeared occasionally_presumably either from dust, persistence of previous aerosols, or, more likely, from the tester's hands and clothes. The air scrubber failed to eliminate this. Challenge aerosol controls usually gave counts of 400 or above.

The tests have been scored as follows:

(1) Nil-no observable difference between the test and the challenge control (even with reduced challenges, ie, $2 \times 10^{3}$ spores).

(2) Poor-repeated leaks of 20-50 particles/55 1, especially from the severer challenges.

(3) Good-challenges of $2 \times 10^{4}$ spores from $15 \mathrm{~cm}$ position all contained, occasional leak from either $2 \times 10^{6}$ spores or $2 \times 10^{4}$ liberated from $2.5 \mathrm{~cm}$.

(4) Excellent-no counts above the background (ie, 5/55 l).

The table shows that airflows of $1 \mathrm{~m} / \mathrm{s}$ provided excellent containment; $1.5 \mathrm{~m} / \mathrm{s}$ passing through glove ports in cabinet 18 was only 'good', presumably because of turbulence associated with such a high speed, and the horizontal airflow pattern of cabinet 17 also gave only 'good' containment (particularly with equipment inside). Flows of $0.85 \mathrm{~m} / \mathrm{s}$ contained all but the severest challenges, but $0.7 \mathrm{~m} / \mathrm{s}$ and below gave poor containment except in cabinet 8 , which was a glove box.

\section{Effect of air speed on containment}

The effect of liberating various challenges $2.5 \mathrm{~cm}$ behind the working aperture at differing air speeds in three cabinets is seen in Table 2. The cabinets varied slightly, and backgrounds of up to 6 particles/55 1 created some confusion (despite the air scrubber). Even so, leaks of 11 particles were found at $0.6 \mathrm{~m} / \mathrm{s}$ in two units, and greater leaks in all three at $0.5 \mathrm{~m} / \mathrm{s}$.

\section{Effect of a door slam}

This was tested in cabinet 12 sited in a medium-sized $\left(42 \mathrm{~m}^{2}\right)$ laboratory $4.5 \mathrm{~m}$ from the door. Twelve aerosols were liberated from $2.5 \mathrm{~cm}$, and the door was slammed during sampling. The cabinet had contained this aerosol satisfactorily, but the door slams produced a mean count of 6.4 , which included two significant leaks of 25 particles/55 1 .

\section{Contamination of interior surfaces}

Table 1 records surface contamination as an average count of viable particles per assay dish (usually from three tests, ie, six dishes). Cabinets with low airflow had gross contamination, the cabinets with restricted fronts $(7,8,18)$, ie, glove boxes, and one with a horizontal airflow (17) had moderate contamination, presumably because of turbulence; those with open fronts and adequate airflow had remarkably little.

Spore sprays from outside were done in two cabinets, both with minimal surface contamination in the previous tests. In one case there was a heavy deposition of particles on the plates, and in the other virtually none. Some $9 \mathrm{~cm}$ diameter plates were also exposed on the floors of these cabinets and changed hourly during the working day. In one cabinet only 
1 particle was recovered from 18 plates, and in the other 18 were recovered from 30 plates.

\section{Effect of glove ports}

Table 3 shows that airflows of 0.5 and $1.6 \mathrm{~m} / \mathrm{s}$ through glove ports produced more surface contamination than $0.15 \mathrm{~m} / \mathrm{s}$ across a fully open front, although the cabinet air changed 11 times/min in the first instance and three times in the second. Table 4 shows that these findings were confirmed by contamination of the author's hand.

Table 3 Floor contamination on one open-fronted cabinet fitted with variable-speed motor

\begin{tabular}{|c|c|c|c|c|c|c|}
\hline \multirow{2}{*}{$\begin{array}{l}\text { Air } \\
\text { changes } \\
\text { per } \\
\text { minute }\end{array}$} & \multicolumn{2}{|c|}{$\begin{array}{l}\text { Air speed across } \\
\text { aperture }(\mathrm{m} / \mathrm{s})\end{array}$} & \multicolumn{4}{|c|}{$\begin{array}{l}\text { No. of particles } \\
\text { impacted on floor }\end{array}$} \\
\hline & $\begin{array}{l}\text { Open-front } \\
\text { mode }\end{array}$ & $\begin{array}{l}\text { Glove port } \\
\text { mode }\end{array}$ & $\begin{array}{l}\text { Open-fro } \\
L\end{array}$ & $\begin{array}{r}\text { ont } \\
R\end{array}$ & $\begin{array}{l}\text { Glove po } \\
L\end{array}$ & $\begin{array}{r}\text { ort } \\
R\end{array}$ \\
\hline 32 & 1.5 & & 32 & 42 & & \\
\hline 21 & 1.0 & & 25 & 18 & & \\
\hline 16 & 0.75 & & 5 & 5 & & \\
\hline 11 & 0.5 & $1 \cdot 6$ & 6 & 39 & 584 & 60 \\
\hline 9 & 0.4 & & 17 & 33 & & \\
\hline 4 & 0.2 & & 23. & 36 & & \\
\hline 3 & 0.15 & 0.5 & 17 & 17 & +++ & $+t+$ \\
\hline 2 & 0.1 & & $+t+$ & +++ & & \\
\hline
\end{tabular}

+++ Confluent growth.

$\mathbf{L}=$ left-hand assay dish.

$\mathbf{R}=$ right-hand assay dish

Table 4 Hand contamination

\begin{tabular}{lrrrrrr}
\hline Air flow $(m / s)$ & \multicolumn{3}{c}{ Open front } & \multicolumn{4}{c}{ Glove port } \\
\hline $1 \cdot 0$ & 0 & 0 & & 0 & 4 & 1 \\
$0 \cdot 5$ & 0 & 0 & 0 & 16 & 14 & 2 \\
$0 \cdot 25$ & 0 & 0 & 3 & 18 & 29 & \\
$0 \cdot 1$ & 43 & 19 & 17 & 39 & 30 & \\
Controls & & & & & & \\
Fan off $(0)$ & 25 & 33 & & & & \\
Sterile glove & 0 & 0 & & & & \\
\hline
\end{tabular}

Figure $=$ Number of bacteria-containing particles recovered from the hand after a 10-second spray at various air speeds.

\section{AIRFLOW MEASUREMENTS}

The electronic vane anemometer sampled a $10 \mathrm{~cm}$ diameter airflow; vane inertia meant that flows of $<0.2 \mathrm{~m} / \mathrm{s}$ were unreadable. The anemometer was very robust and practical; when recalibrated in an open-jet wind tunnel after four years' use only one of the three scales needed minor adjustment. The thermoanemometer was cheap and easy to use and also had a recordable output. The traces produced by the two instruments from the same cabinet are shown in Figure 1. The electronic damping of the vane type (needed to convert pulses into a continuous reading) makes the results easier to interpret,
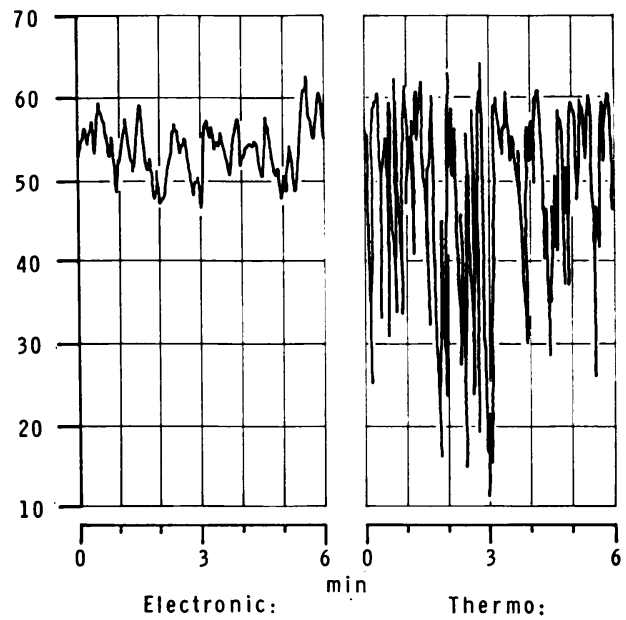

Fig. 1 Comparison of anemometer traces.

and its readings tallied well with the microbiology. However, the needle fluctuated considerably when measuring airflows across a working aperture, and so all readings were observed for at least 5 minutes. Figure 2 shows the trace from a cabinet that recirculated exhaust air into the laboratory, set to work at $0.6 \mathrm{~m} / \mathrm{s}$. Speeds ranged from 0.4 to $0.7 \mathrm{~m} / \mathrm{s}$, although the flow settled to a $10 \%$ variation in a quiet room (door and window shut). Figure 3 shows, by contrast, a tracing from a cabinet that exhausted air from the laboratory. Considerable variations are present; and although obvious disturbances, such as working or door slams are to be expected, the reading failed to settle in a quiet room, presumably because of external air pressures, an effect that was exaggerated by leaving the door open. Walking past a cabinet also produces a lowering of airflow, as seen in Figure 4.

Increased airflow through the edge of the working aperture nearest the door was noted with several

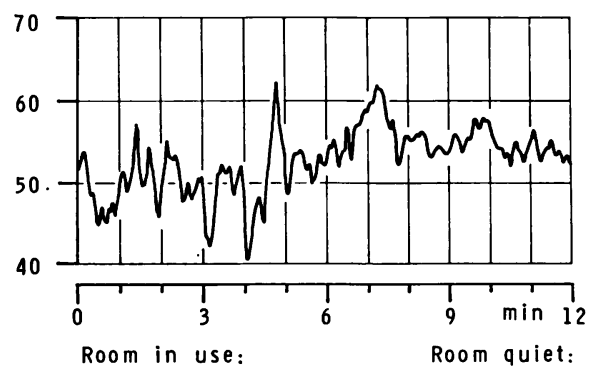

Fig. 2 Airflow in recirculating cabinet $(\mathrm{m} / \mathrm{s} / 100)$ $(50=0.5 \mathrm{~m} / \mathrm{s})$. 


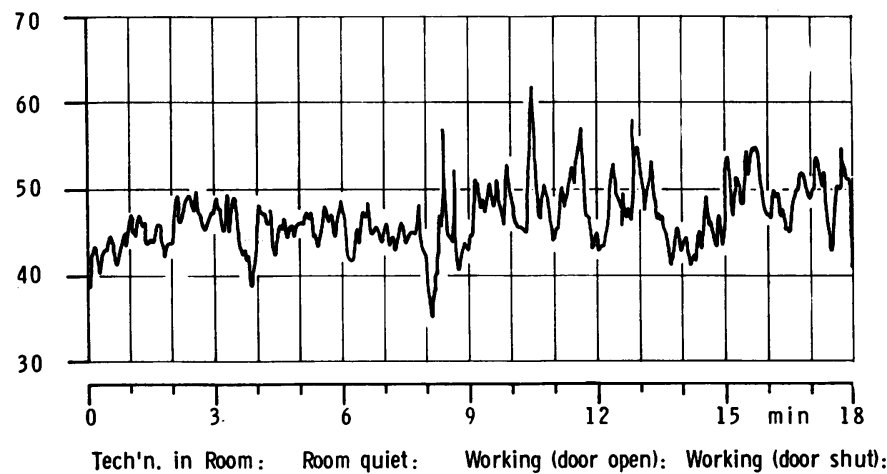

Fig. 3 Airflows in a cabinet exhausted outside $(\mathrm{m} / \mathrm{s} / 40)(50=1.25 \mathrm{~m} / \mathrm{s}, 250 \mathrm{lfm})$.

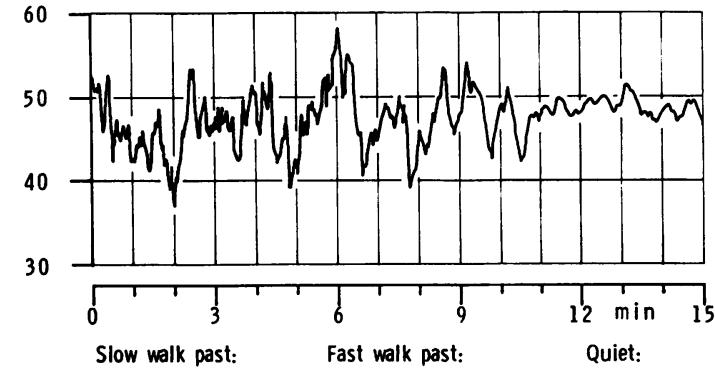

Fig. 4 Walking past a cabinet $(\mathrm{m} / \mathrm{s} / 40)(50=1.25 \mathrm{~m} / \mathrm{s})$.

units (placed at $90^{\circ}$ to the door). The most marked variation was in a cabinet with a $120 \mathrm{~cm}$ wide aperture sited in a small converted toilet. The average airflow was $0.75 \mathrm{~m} / \mathrm{s} ; 17 \mathrm{~m}^{3} / \mathrm{min}$ of air was exhausted, ie, one complete room air change. Consequently, the position of the door (opposite the window and well fitted) made a great difference to the cabinet airflow, which varied from $0.4 \mathrm{~m} / \mathrm{s}$ (window end of aperture-door closed) to $0.8 \mathrm{~m} / \mathrm{s}$ (door end-door open).

\section{Blowback}

Figure 5 shows the reverse airflow coming out of an inoperative cabinet on a windy day. The exhaust port was in the side wall directly facing the wind. The reverse airflow reached $0.5 \mathrm{~m} / \mathrm{s}$ on occasions, and there was a marked pulsing effect. Whether the pulses were due to the resistance of the filter or to vane inertia is impossible to say; pulses were also found on traces taken a few days later with the thermoanemometer. Material stuck on a HEPA filter is held by strong forces and needs a much greater force for removal than impaction. A Hoover motor attached to the exhaust duct of one cabinet was used to provide artificial 'blowback', while the laboratory air was sampled for spores (as the cabinet

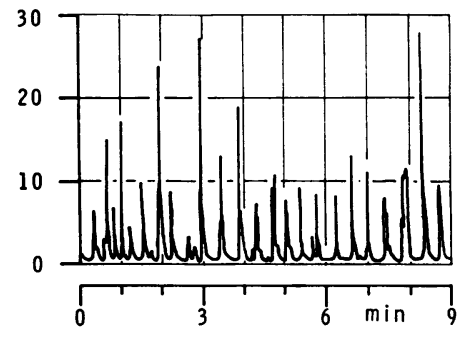

Fig. 5 Blowback on a windy day $(\mathrm{m} / \mathrm{s} / 100)$ $(50=0.5 \mathrm{~m} / \mathrm{s})$.

had been used for tests over six months). There was no contamination of the laboratory air from the blowback nor from shaking the prefilter (which was clean). However, some large infected particles fell from the prefilter onto assay plates on the cabinet floor. In practice, the prefilter or a grid (if provided) may hold a lot of fluff in a very loose manner (Fig. 6), which could be readily dislodged.

\section{Discussion}

Terjesen and Cherry (1947) described filter tests with aerosols of $\boldsymbol{B}$. subtilis spores generated in a Collison spray and found that a $10^{6} / \mathrm{ml}$ suspension provided 500 particles $/ 551$ of air. Other workers (eg, Darlow, H. M. - 1972 personal communication) have used spores to test safety cabinets, and both the National Sanitation Foundation (NSF) Standard (1976) and the forthcoming British Standard rely on such tests. The BIRD micronebuliser is very similar to the Vaponefrin model specified by the NSF, and happily both that Standard and Dimmick and Akers (1969) recommended operation at $10 \mathrm{psi}(69 \mathrm{kPa})$, which gave vane anemometer readings of $0.3 \mathrm{~m} / \mathrm{s}$ at $2.5 \mathrm{~cm}$ and nil at $15 \mathrm{~cm}$ in front of the micronebuliser. Both Standards require a $10^{8}$ spore 


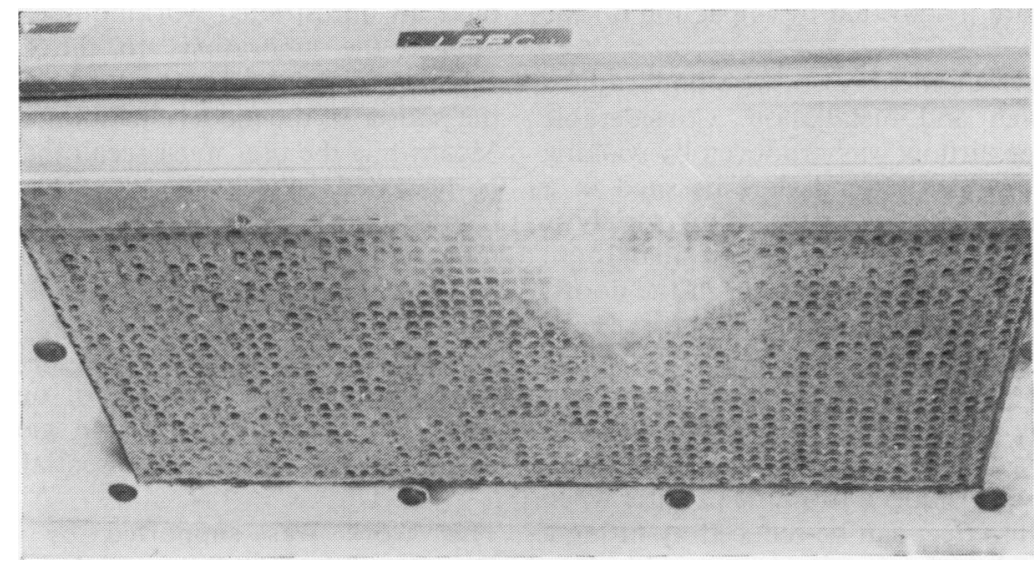

Fig. 6 Dust on the grid of a safety cabinet.

challenge-somewhat above the present 10 tests with $2 \times 10^{6}$; however, all of the 'excellent' and probably the 'good' cabinets would be expected to pass the containment specifications. The choice of $2 \times 10^{4}$ spores, however, provided a challenge well above the number of microbes liberated by normal laboratory procedures (Wedum, 1953) except for blending, sonication, or tube shatter during centrifugation. Although 'sterile' sets of tests were a rarity, no doubts were left about inadequate cabinets. The choice of 5 particles/55 1 as a maximum number for room background is below the minimum infectious dose of Coxiella burneti or francisella (Wedum, 1964). Chatigny and Clinger (1969) noted that a leak of 6 particles/55 1 after dilution with laboratory air meant that an operator would require 1000 minutes to acquire a 10-organism dose, and concluded that this represented reasonably safe operation. Thus, even if some 'background' was actually due to leakage of spores from the cabinet rather than room contamination, it seems reasonable to conclude that the cabinet was satisfactory. The failure to get a completely clean background led to the use of a 'protection factor' rather than an absolute figure in the British Standard.

Containment test results from the cabinet survey correlated reasonably well with the air velocity measurements and imply that an airflow of $1 \mathrm{~m} / \mathrm{s}$ provides excellent protection, but flows below $0.75 \mathrm{~m} / \mathrm{s}$ may allow leaks. Higher speeds are said to create turbulence problems. The containment tests with the micronebuliser only $2.5 \mathrm{~cm}$ behind the working aperture were extremely stringent, verging on the impractical. Nevertheless these results are in keeping with other work. For example, Barbeito and Taylor (1968) condemned a cabinet working at
$0.25 \mathrm{~m} / \mathrm{s}$. Even in a quiet room cabinet airflows measured with the electronic anemometer (despite its damping) varied by $\pm 20 \%$, and movement inside the laboratory increased this considerably. Indeed, Chatigny (1961) found that walking at $2 \mathrm{mph}$ created backdraughts up to $0.85 \mathrm{~m} / \mathrm{s}$. He recommended a $0.75 \mathrm{~m} / \mathrm{s}$ airflow, as did the National Institute of Health for fume cupboards (Barkley, W. E., 1977-personal communication).

The surface contamination tests revealed several interesting facts. Firstly, a restricted working aperture, for example, glove ports without gloves, creates considerable contamination of the cabinet interior (and the user's hands). Such units should be used only with gloves. If an open/sealed cabinet is needed, a bolt-on, sealable panel with glove ports is required to convert an open front into a glove-box. A variable speed fan may be needed so that excessive airflow is not provided in the 'glove port' mode. Secondly, aerosols liberated during manipulations in a glove box are likely to be deposited on surfaces (including equipment) inside; the contents must be regarded as potentially contaminated and require formalin disinfection (Newsom and Walsingham, 1974) or autoclaving before removal into the laboratory. Finally, and surprisingly, the protection of cabinet surfaces from 'cross contamination' by aerosols generated within it provided by a 'good' or 'excellent' open-fronted exhaust cabinet was equal to that found in a class II cabinet (Newsom, 1979) where the work is continuously flushed by a flow of sterile air; furthermore, in one of the two cabinets tested with a challenge aerosol from the laboratory the 'product protection' (ie, surface contamination) equalled that of a good class II unit. Presumably the aerosols become entrained in the air flowing through 
the cabinet and are inactivated by impaction on the filter.

The airflow measurements also have implications for cabinet design and installation. Considerable disturbance of the airflow was produced by walking past the cabinet, which should thus be sited in a quiet part of the room. An adequate air supply is needed to allow proper function, and in a small room special provision, for example, louvres in the doors, may be needed. Air-conditioning vents must be avoided, however, as the resultant cross currents may disturb the cabinet airflow (Rake, 1978).

Blowback can reach quite serious proportions; although a $1 \mathrm{~m} / \mathrm{s}$ airflow is unlikely to be neutralised, debris may be dislodged from the prefilter when the fan is off. This effect can be reduced by fitting a front sealing panel (night door) to create a block to airflow when the cabinet is not in use, or by providing an anti-blowback valve in the ducting or a suitably shaped exhaust exit. A 'pixie hat' on a flat roof allows wind to pass across from any direction and sometimes produces a venturi suction effect; but air movement up and down walls or sloping roofs can overcome the most carefully designed cowls. Buildup of debris on the pre-filter implies a need for regular changing, for it may reach amounts that can be readily dislodged without affecting the airflow and so be undetectable. Grids (if provided) need to be cleared regularly.

Cabinets that recycled filtered air to the laboratory were less affected by air currents and, of course, immune to blowback, so in this respect they were better than those that exhausted the air outside. However, few laboratories can test filter function on a routine basis; and also fumigant gases must be exhausted from the laboratory, so that the recycling unit is inappropriate for most users.

Occasionally, during aerosol tests from the $2.5 \mathrm{~cm}$ position, the spray could be seen entering the laboratory, but no counts were obtained in the slit sampler presumably because the aerosol was immediately sucked back into the cabinet. However, none of the cabinets tested had an aerodynamic front, and O. M. Lidwell (1978-personal communication has shown that smoke can leak from the floor at the front of some cabinets into the laboratory, and that this effect is minimised by using an aerodynamic 'wing' along the bottom edge of the working aperture. No doubt a 'minimum turbulence' pathway for the air going through the cabinet could be designed allied to the correct size of exhaust filter. Such a unit would, however, have to be practical; a curved floor, for example, would be hard to work with.

The Scientific and Technical Branch of the Department of Health and Social Security maintains a list of these 'good' and 'excellent' cabinets which have an unrestricted working aperture and exhaust outside the laboratory. In the future, hopefully, cabinets will be designed to the British Standard, and the poorer of the models mentioned here will vanish. Meanwhile the user must recall that total safety can be provided only by the glove box since the openfronted unit occasionally may be inactivated by fan failure and provides no protection for the operator's hands, which may well be infected by direct contact with the work. However, the open front is still appropriate for routine work in hospital laboratories where risk and convenience of operation must be balanced out, but disposable gloves and nearby handwashing facilities are essential.

This work was supported by the Engineering Division of the DHSS through Inter-Authority Study Group No. 9, to whom I am most grateful. Dr O. M. Lidwell and Surg. Cdr H. M. Darlow made many helpful suggestions for the work.

\section{References}

Barbeito, M. S., and Taylor, L. A. (1968). Containment of microbial aerosols in a microbiological safety cabinet. Applied Microbiology, 16, 1225-1229.

Chatigny, M. A. (1961). Protection against infection in the microbiological laboratory: devices and procedures. Advances in Applied Microbiology, 3, 131-192.

Chatigny, M. A., and Clinger, D. I. (1969). In $A n$ Introduction to Experimental Aerobiology, edited by R. L. Dimmick and A. B. Akers, p. 194. Wiley, New York.

Darlow, H. M. (1961). The provision of clean air. Laboratory Animal Centre Collected Papers, 10, 65-69.

Dimmick, R. L., and Akers, A. B. (1969). In An Introduction to Experimental Aerobiology, edited by R. L. Dimmick and A. B. Akers, p. 26. Wiley, New York.

Line, S. J. (1972). Safety of portable inoculation cabinets. Journal of Clinical Pathology, 25, 93-94.

National Sanitation Foundation (1976). Standard No. 49 for Class II Cabinetry. Ann Arbor, Michigan.

Newsom, S. W. B. (1974). A test system for the biological safety cabinet. Journal of Clinical Pathology, 27, 585-589.

Newsom, S. W. B. (1979). The class II (laminar flow) biological safety cabinet. Journal of Clinical Pathology, 32, 505-513.

Newsom, S. W. B., and Walsingham, B. M. (1974). Sterilisation of the biological safety cabinet. Journal of Clinical Pathology, 27, 921-924.

Pike, R. M. (1976). Laboratory-associated infections: Summary and analysis of 3921 cases. Health Laboratory Sciences, 13, 105-114.

Rake, B. W. (1978). Influence of crossdraughts on the performance of a biological safety cabinet. Applied and Environmental Microbiology, 36, 278-283.

Shepard, C. C., May, C. W., and Topping, N. H. (1945). A protective cabinet for infectious disease laboratories. 
Journal of Laboratory and Clinical Medicine, 30, 712-716.

Solotorovsky, M., Robinson, H. J., and Kniazuk, M. (1953). Design and operation of a laboratory for experimental tuberculosis. American Review of Tuberculosis, 68, 212-219.

Terjesen, S. G., and Cherry, G. B. (1947). The removal of microorganisms from air by filtration. Transactions of the Institution of Chemical Engineers, 25, 89-96.

van den Ende, M. (1943). An apparatus for the safe inoculation of animals with dangerous pathogens. Journal of Hygiene, 43, 189-194.
Wedum, A. G. (1953). Bacteriological safety. American Journal of Public Health, 43, 1428-1437.

Wedum, A. G. (1964). Laboratory safety in research with infectious aerosols. Public Health Reports, 79, 619-633.

Williams, R. E. O., and Lidwell, O. M. (1957). A protective cabinet for handling infective material in the laboratory. Journal of Clinical Pathology, 10, 400-402.

Requests for reprints to: Dr S. W. B. Newsom, Department of Bacteriology, The John Bonnett Clinical Laboratories, Addenbrooke's Hospital, Cambridge CB2 2QQ. UK. 